\title{
Hypoxia-induced cell death in human malignant glioma cells: energy deprivation promotes decoupling of mitochondrial cytochrome $c$ release from caspase processing and necrotic cell death
}

\author{
JP Steinbach ${ }^{*, 1}$, H Wolburg ${ }^{2}$, A Klumpp $^{1}$, H Probst $^{3}$ and \\ M Weller ${ }^{1}$ \\ ${ }^{1}$ Laboratory of Molecular Neuro-Oncology, Department of Neurology, University \\ of Tübingen, School of Medicine, Tübingen, Germany \\ 2 Institute of Pathology, Division of Molecular Pathology, University of Tübingen, \\ School of Medicine, Tübingen, Germany \\ ${ }^{3}$ Institute of Physiological Chemistry, University of Tübingen, Germany \\ * Corresponding author: JP Steinbach, Laboratory of Molecular Neuro- \\ Oncology, Department of Neurology, University of Tübingen, Medical School, \\ Hoppe-Seyler-Strasse 3, 72076 Tübingen, Germany. Tel: +49-7071-2982141; \\ Fax: +49-7071-295260; E-mail: joachim.steinbach@uni-tuebingen.de
}

Received 26.6.02; revised 9.1.03; accepted 10.3.03

Edited by JA Cidlowski

\begin{abstract}
Hypoxia induces apoptosis in primary and transformed cells and in various tumor cell lines in vitro. In contrast, there is little apoptosis and predominant necrosis despite extensive hypoxia in human glioblastomas in vivo. We here characterize ultrastructural and biochemical features of cell death in LN229, LN-18 and U87MG malignant glioma cells in a paradigm of hypoxia with partial glucose deprivation in vitro. Electron microscopic analysis of hypoxia-challenged glioma cells demonstrated early stages of apoptosis but predominant necrosis. ATP levels declined during hypoxia, but recovered with re-exposure to normoxic conditions unless hypoxia exceeded $8 \mathrm{~h}$. Longer hypoxic exposure resulted in irreversible ATP depletion and delayed cell death. Hypoxia induced mitochondrial release of cytochrome $c$, but there was no cleavage of caspases $3,7,8$ or 9 , and no DNA fragmentation. Ectopic expression of $B C L-X_{L}$ conferred protection from hypoxia-induced cell death, whereas the overexpression of the antiapoptotic proteins X-linked-inhibitor-of-apoptosisprotein and cytokine response modifier-A had no effect. These findings suggest that glioma cells resist adverse effects of hypoxia until energy stores are depleted and then undergo necrosis rather than apoptosis because of energy deprivation.
\end{abstract}

Cell Death and Differentiation (2003) 10, 823-832. doi:10.1038/ sj.cdd. 4401252

Keywords: glioma; hypoxia; apoptosis; necrosis; cytochrome $c$; caspase; BCL- $\mathrm{X}_{1}$; ATP
Abbreviations: APAF 1, apoptotic protease activating factor 1; CD95L, CD95 ligand; Crm-A, cytokine response modifier-A; ECL, enhanced chemiluminescence; GFP, green fluorescent protein; TUNEL, terminal dUTP in situ nick end-labeling; VEGF, vascular endothelial growth factor; XIAP, X-linked-inhibitor-of-apoptosisprotein.

\section{Introduction}

Extensive hypoxia is a hallmark of glioblastoma and other solid tumors. ${ }^{1-3}$ Already at early stages of tumorigenesis, tumor hypoxia may be precipitated by regression of co-opted host vasculature, resulting in hypoxic tumor cell death and thus selective pressure for hypoxia-resistant clones. ${ }^{4,5}$ Ultimately, however, the remaining tumor is rescued by robust angiogenesis at the tumor margin. In established tumors, chronic hypoxia is caused by increased metabolic activity and rapid tumor cell growth outscaling tumor neoangiogenesis and compromising the vascular supply of oxygen and nutrients. In addition, acute tumor hypoxia can be brought about by tumor vessel occlusion via thrombosis ${ }^{6,7}$ or by fluctuations in the oxygenation of disordered tumor vasculature. $^{8,9}$ Further, antiangiogenic therapeutic strategies can result in hypoxia and tumor cell death. ${ }^{10,11}$

Tumor hypoxia is relevant for (i) the selection of clones resistant to hypoxia-induced cell death and (ii) the biological behavior and response to therapy of the hypoxic tumor cell fraction. Hypoxia-induced cell death in E1A and Ha-rastransformed cell lines, ${ }^{12}$ several nonglioma tumor cell lines ${ }^{13,14}$ and nontransformed cells ${ }^{15}$ may take place predominantly by apoptosis in vitro. In contrast, glioblastoma cell death in vivo is predominantly necrotic, ${ }^{7,16}$ while the amount of apoptosis is generally low. ${ }^{17}$ Apoptotic changes defined by DNA strand breaks detected by terminal dUTP in situ nick end-labeling (TUNEL) are predominantly located among pseudopalisading perinecrotic cells ${ }^{18,19}$ which express vascular endothelial growth factor (VEGF), ${ }^{20}$ suggesting focal areas of hypoxia and a graded response of glioma cells to hypoxia. The small amount of apoptosis despite extensive tumor hypoxia suggests the development of resistance to hypoxia-induced apoptosis in glioblastomas by alterations in the cell death pathway including both short-term effects such as upregulation of antiapoptotic proteins ${ }^{21}$ and genetic selection for cells with defects in the apoptotic pathway. ${ }^{12,22,23}$ The apparent resistance to hypoxia-induced cell death translates also into clinical relevant adverse outcomes, since there is a worse prognosis for patients with extensively hypoxic solid tumors, ${ }^{6,24}$ while both a higher amount of apoptosis and a low ratio of proliferation to apoptosis in glioblastomas may indicate a better prognosis. ${ }^{25,26}$ 
We here characterized the mode and biochemical features of hypoxia-induced cell death in malignant glioma cell lines in vitro. To model realistic conditions of the tumor microenvironment, we restricted glucose concentration in the medium to $2 \mathrm{mM}$ for the hypoxic incubations, since many experimental studies have shown similar decreases in glucose concentration in the center of solid tumors in parallel to increasing hypoxia. ${ }^{27-29}$ In particular, we studied ATP levels during hypoxia, since the mode of cell death can be ATP-dependent, with ATP acting as a molecular switch between apoptosis and necrosis in some paradigms. ${ }^{30,31}$

\section{Results}

\section{Predominant necrosis and abortive apoptotic changes in hypoxia-induced cell death}

The morphological features of hypoxia-induced glioma cell death were characterized by electron microscopy (EM). Primarily, cell death after hypoxia followed by normoxic recovery for $24 \mathrm{~h}$ with replenishment of glucose was studied. In the LN-229 cell line, there were only few cells which displayed apoptotic features at early time points, including cytoplasmic blebbing, nuclear chromatin condensation and margination with rare formation of apoptotic bodies. Necrotic changes, including mitochondrial swelling and organelle disruption, cytoplasmic vesiculation, vacuolization and rupture of the cell membrane at later time points were predominant (Figure 1a-d). In U87MG cells, early apoptotic changes were more pronounced, and cytoplasmic integrity was better preserved in the initial stages. However, at later time points, there was necrosis similar to LN-229 cells (Figure 1e-h). LN-229 cells were prepared for EM also directly following hypoxia of 8,12 and $16 \mathrm{~h}$ to analyze early morphological changes. There were necrotic changes similar to those described above, but nuclear chromatin condensation and margination were less pronounced (cells exposed to hypoxia for $16 \mathrm{~h}$ are shown in Figure 1i). For comparison of typical apoptotic changes, LN-229 cells were exposed to (CD95 ligand) CD95L in a parallel experiment (Figure 1j).

In LN-18 cells, the morphological consequences of hypoxia occurred earlier than in LN-229 and U87MG cells. To investigate the time course of cell death induction, LN-18 cells were fixed for electron microscopy directly after hypoxia (Figure 2a-d) or after a $24 \mathrm{~h}$ period of normoxic recovery (Figure 2e-h). Compared with the morphology seen immediately after hypoxia, more prominent early apoptotic features developed in a delayed fashion after 8 and $12 \mathrm{~h}$ of hypoxia and subsequent further culturing at normoxia, with nuclear chromatin condensation and formation of apoptotic bodies in some cells. As in the LN-229 and U87MG cell lines, necrotic changes prevailed at later time points, ultimately leading to cell membrane disruption. The classical ultrastructural end stages of apoptosis (pyknotic cells with fragmented nuclei and apoptotic bodies, preserved cell membrane) which occur in these cells after treatment with death ligands, Teniposide (VM26), or other stimuli as described in previous studies ${ }^{32-34}$ did not develop in either cell line during hypoxia-induced cell death.
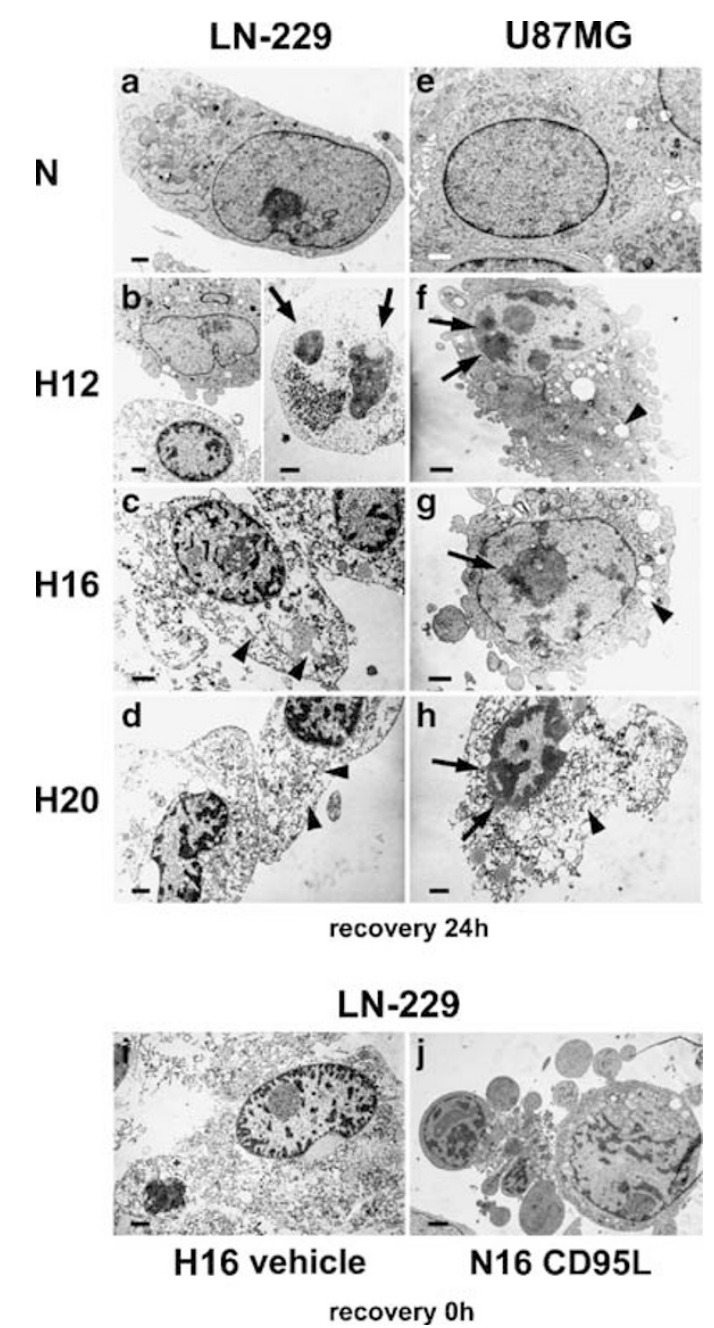

Figure 1 Ultrastructural features of hypoxia-induced cell death in LN-229 and U87MG malignant glioma cells. (a-h). The cells were exposed to normoxia or hypoxia and $24 \mathrm{~h}$ normoxic recovery and prepared for electron microscopy. (a,e) Normoxic LN-229 and U87MG cells (N). (b-d) LN-229 cells exposed to hypoxia for $12-20 \mathrm{~h}$. Note the features of early apoptotic death with cytoplasmic blebbing (upper cell in $\mathbf{b}$ ), nuclear chromatin condensation (b-d) and margination (b, left panel, lower cell) and occasional formation of apoptotic bodies (B, right panel, arrows) as well as early and prominent necrotic changes with disruption of organelle integrity and cytoplasmic vesiculation and vacuolization (arrowheads in $\mathbf{c}, \mathrm{d})$. (f,g,h) U87MG cells exposed to hypoxia for 12-20 h. Cytoplasmic blebbing $(\mathbf{f}, \mathbf{g})$, nuclear chromatin condensation (arrows in $\mathbf{f}-\mathbf{h}$ ) and margination (h) are present in some cells, as well as disruption of organelle integrity, cytoplasmic vesiculation and vacuolization (arrowheads in $F, G, H$ ) at later stages. (i, k) LN229 cells were exposed to hypoxia for $16 \mathrm{~h}$ (i) or to $100 \mathrm{U} / \mathrm{ml} \mathrm{CD95L}$ for $16 \mathrm{~h}$ under normoxia $(\mathrm{f})$ and were prepared for electron microscopy immediately thereafter (scale bar $=1 \mu \mathrm{M}$ )

\section{No specific Annexin V binding occurs during hypoxic cell death}

To further characterize the mode of hypoxic cell death in this paradigm, Annexin $\mathrm{V}$ binding assays were performed in $\mathrm{LN}-18$ and LN-229 cells. No specific apoptotic changes (i.e. Annexin $\mathrm{V}$ binding in cells not taking up propidium iodide, lower right quadrant) were detected. Some propidium iodide positive cells also stained positive for Annexin V, a finding consistent 
with necrosis (upper right quadrant). Results in $\mathrm{LN}-18$ cells stained immediately after hypoxia are shown in Figure 3. Similar results were obtained with $\mathrm{LN}-229$ cells and after additional normoxic recovery (not shown).

\section{Progressive ATP depletion during hypoxia determines hypoxic cell death}

To analyze cellular energy homeostasis during hypoxia and subsequent normoxic recovery of glioma cells, ATP levels

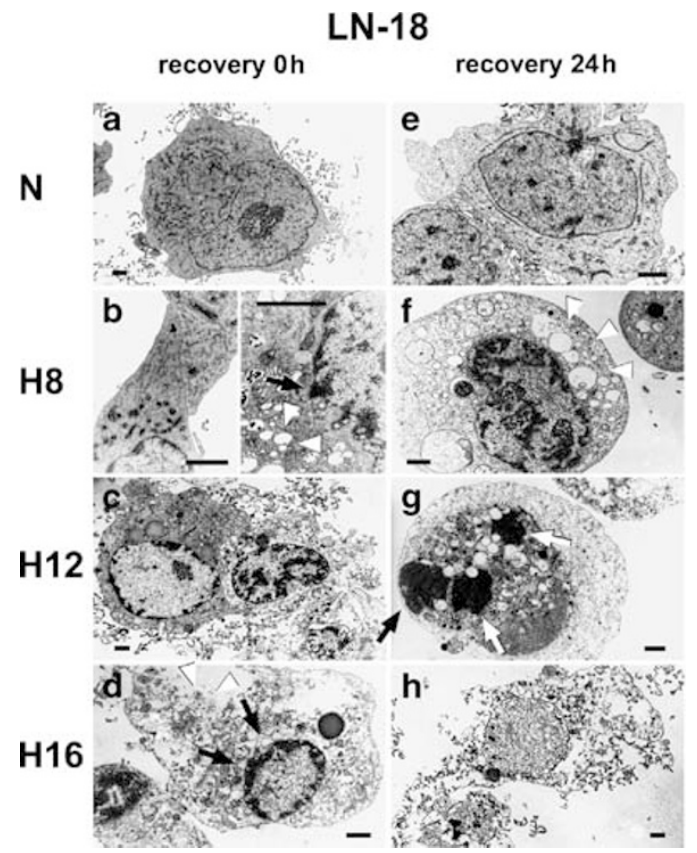

Figure 2 Ultrastructural features of hypoxia-induced cell death in LN-18 malignant glioma cells. The cells were incubated under normoxia or hypoxia for 8 12 or $16 \mathrm{~h}$ and prepared either immediately for electron microscopy to detect early morphological changes (a-d), or after $24 \mathrm{~h}$ of normoxic recovery $(\mathrm{e}-\mathrm{h}) .(\mathrm{a}, \mathrm{d})$ Normoxic cells (N). (b-d) LN-18 cells fixed directly after hypoxia. Note the primary cytoplasmic damage with vesiculation and vacuolization (arrowheads in $\mathbf{b}$ and $\mathbf{d}$ ) and a lesser degree of nuclear changes with nuclear indentations (arrows in $\mathbf{b}$ ) and some chromatin condensation (arrows in d). (f-h) LN-18 cells fixed $24 \mathrm{~h}$ after recovery from hypoxia. Early apoptotic changes are emerging only in some cells, with nuclear chromatin condensation (shown in f) in parallel with cytoplasmatic vesiculation and vacuolization (arrowheads in $\mathrm{f}$ ) and rare formation of apoptotic bodies (arrows in $\mathbf{g}$ ). Necrosis as described above is prominent at later time points $(\mathrm{H})$. (scale bar $=1 \mu \mathrm{M})$ were monitored in LN-229 cells and correlated with cell death as assessed by $\mathrm{LDH}$ release. At 4 and $8 \mathrm{~h}$ of hypoxia, cellular ATP levels were reduced, but recovered during additional normoxic incubation with glucose supplementation (Figure 4a). While cell death took place during hypoxia (white bars in Figure $4 b$ ), there was no further delayed cell death during the recovery period following 4 and $8 \mathrm{~h}$ of hypoxia (black bars in Figure 4b). In contrast, ATP stores were irreversibly depleted at $12 \mathrm{~h}$ of hypoxia and at later time points, and delayed cell death occurred.

\section{Hypoxic cell death is dependent on glucose concentration}

To define the threshold for glucose concentrations in the medium necessary for survival under hypoxic conditions, LN229 cells were incubated under hypoxia with glucose concentrations of $2 \mathrm{mM}, 5 \mathrm{mM}$ and full serum-free medium (25 mM glucose). At a starting concentration of $2 \mathrm{mM}$, glucose was less than $1 \mathrm{mM}$ at $\mathrm{H} 8$, where significant cell death emerged (Figure $5 \mathrm{a}$ ). $25 \mathrm{mM}$ and $5 \mathrm{mM}$ glucose in the media protected the cells from hypoxia-induced cell death (Figure $5 b, c)$. In addition, glucose concentrations above $2 \mathrm{mM}$ protected against hypoxia-induced ATP depletion as described previously ${ }^{35}$ and cytochrome $c$ release (data not shown).

\section{Mitochondrial cytochrome $c$ release fails to promote caspase processing during hypoxia-induced cell death}

To characterize the hypoxia-induced cell death pathway at a biochemical level, mitochondrial cytochrome $c$ release, caspase processing and DNA fragmentation were examined as three salient features typically accompanying apoptosis. There was pronounced cytochrome $c$ release from mitochondria into the cytosol from $\mathrm{H} 8$ on in $\mathrm{LN}-229$ cells (Figure 6a). Similar results were obtained in LN-18 and U87MG cells (not shown). Swelling of mitochondria with distortion of the cristae was observed in LN-229 cells exposed to hypoxia for $8 \mathrm{~h}$ and immediately thereafter prepared for electron microscopy as a possible morphological correlate of mitochondrial injury (Figure 6b). In contrast to other models of cell death, the observed release of cytochrome $c$ failed to promote the processing of caspases $3,7,8$ and 9 during hypoxia-induced cell death in $\mathrm{LN}-18$ cells. In contrast, caspase cleavage was

LN-18

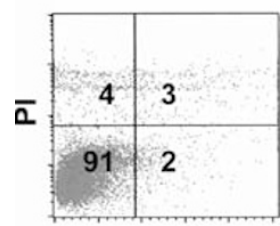

N

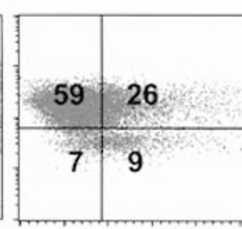

CD95L

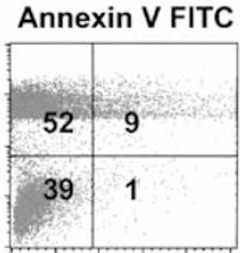

H8

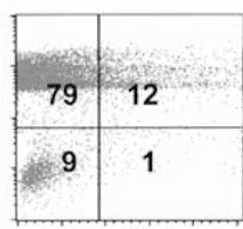

$\mathrm{H} 12$

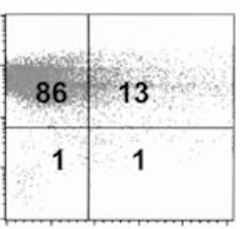

H16

Figure 3 Annexin V binding in hypoxia-induced cell death. LN-18 cells were exposed to normoxia or hypoxia and analyzed immediately thereafter for Annexin $\mathrm{V}$ binding and propidium iodide uptake ( $\mathrm{Pl}$ ). $\mathrm{LN}-18$ cells exposed to $\mathrm{CD} 95 \mathrm{~L}$ in the presence of cycloheximide were employed as positive controls. No Annexin $\mathrm{V}$ binding in viable cells not taking up PI was observed in hypoxia-induced cell death, indicating the absence of apoptosis 


\section{$\square-$ recovery $0 h-$ recovery $24 h$}
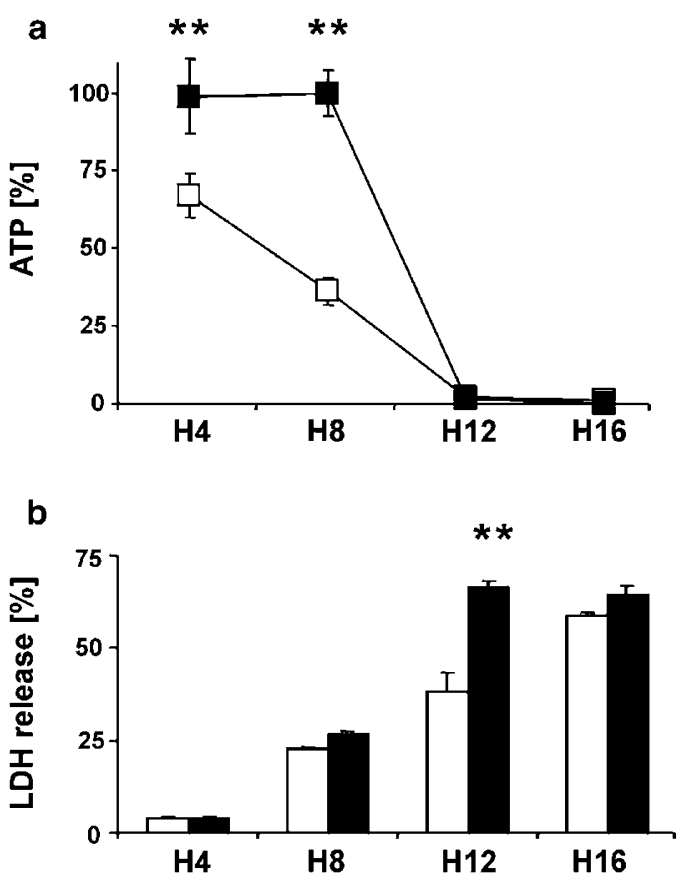

Figure 4 Irreversible ATP depletion precedes delayed hypoxia-induced cell death. LN-229 cells were exposed to normoxia or hypoxia and either analyzed immediately or after $24 \mathrm{~h}$ of normoxic recovery. (a) Cellular ATP content was determined by luciferase assay. (b) In a parallel assay, cell death was assessed by LDH release $\left({ }^{* *} P<0.01\right.$ for the comparison of recovery $0 \mathrm{~h}$ versus recovery $24 \mathrm{~h}$ after hypoxia, Student's $t$-test)

readily induced by CD95L (Figure 6c). Similar results were obtained in LN-229 and U87MG cells (data not shown). Further, hypoxia did not generate DEVD-amc-cleaving caspase activity corresponding to the processing of caspases 3 or 7 (Figure 6d). DNA fragmentation, a downstream consequence of caspase activity mediated by DNA fragmentation factor (DFF) 45, was not detectable in LN-229 cells after hypoxia. In contrast, basal DNA fragmentation under normoxic conditions decreased following 12 and $16 \mathrm{~h}$ of hypoxia (Figure 6e). The absence of caspase cleavage, DNA fragmentation and late-stage apoptotic morphology suggested that the apoptotic cascade was largely disabled at the step of cytochrome $c$-dependent caspase processing.

\section{Ectopic expression of BCL- $\mathrm{X}_{\mathrm{L}}$ protects glioma cells from hypoxia-induced cell death}

Although mitochondrial damage and the release of cytochrome $c$ are commonly modulated by BCL-2 family proteins, the protein levels of $B C L-2, B C L-X_{L}$ and $B A X$ remained unchanged during hypoxia (data not shown). BCL- $X_{L}$ has been shown to protect from hypoxic cell death, and previous work from our laboratory has shown that ectopic expression of $B C L-X_{L}$ in $L N-18$ and $L N-229$ cells also inhibits death receptor-mediated apoptosis presumably by preventing mitochondrial cytochrome $c$ release. ${ }^{36}$ We therefore investi- gated hypoxia-induced cell death in $\mathrm{LN}-18$ and $\mathrm{LN}-229$ cells transfected with $B C L-X_{L}$ : enhanced expression of $B C L-X_{L}$ conferred significant protection from hypoxia-induced cell death in both cell lines. Results for $\mathrm{LN}-18$ cells are shown in Figure $7 \mathrm{a}$ (note that the difference between $\mathrm{LN}-18$ neo and LN-18 BCL- $X_{L}$ was not statistically significant at $\mathrm{H} 20$ ). However, BCL- $X_{L}$ did not prevent hypoxia-induced ATP depletion (results for LN-18 cells are shown in Figure 7a). This is compatible with anaerobic extramitochondrial ATP generation under hypoxia and a model where mitochondrial injury might be a consequence of energy depletion rather than its cause.

To further characterize the role of inhibitors of apoptosis, LN-229 cells were transduced with a vector encoding the Xlinked-inhibitor-of-apoptosis-protein (XIAP) or a green fluorescent protein (GFP) control vector by adenoviral gene transfer. While XIAP protected cells from CD95L-induced apoptosis under normoxia (Figure 7b, left), it did not protect against hypoxic cell death. To ascertain proper function of the adenovirally transferred XIAP also under hypoxic conditions, we exposed the cells to hypoxia in the presence of CD95L: XIAP was protective solely against the additional cell death caused by CD95L (Figure 7b, right).

Similar, ectopic expression of the viral caspase 8 inhibitor cytokine response modifier-A (crm-A) in LN-229 cells did not confer protection from hypoxic cell death, while efficiently inhibiting CD95 ligand-induced apoptosis (Figure 7c). Despite the lack of detectable caspase cleavage, incubation of $\mathrm{LN}-18$ cells with the broad spectrum protease inhibitor zVAD-fmk conferred protection against hypoxic cell death (Figure $7 d$ ). In contrast, the more specific inhibitors of caspases 3 and 9, zDEVD-fmk and zLEHD-fmk, respectively, did not protect against hypoxia-induced cell death (Figure $7 d$ ). The effect of zVAD-fmk was already detectable immediately following hypoxia, with no additional protection generated during normoxic recovery, and similar data were obtained in LN229 cells (not shown).

\section{Discussion}

Here we have characterized the features of hypoxic cell death of malignant glioma cell lines in vitro in a paradigm of profound hypoxia and partial glucose deprivation. In contrast to classical apoptotic cell death induced by hypoxia in E1A and Ha-ras-transformed cell lines, ${ }^{12}$ several nonglioma tumor cell lines ${ }^{13,14}$ and nontransformed cells, ${ }^{15}$ only early morphological features of apoptosis, but predominant necrosis, became evident by ultrastructural and biochemical analysis in the glioma cell lines. Since the glioma cells investigated in this study are proficient to undergo caspase activation and apoptosis in response to death ligands or cytotoxic drugs, ${ }^{33}$ specific mechanisms must account for the absence of hypoxia-induced apoptosis. Antiapoptotic molecules expressed by glioma cells may prevent hypoxic stimuli from activating the cell death program as long as energy resources and organelle integrity are preserved. Ultimately, cell death ensues when the available nutrients, for example, glucose, are consumed, and cellular ATP is progressively depleted. ${ }^{30}$ This notion is supported by the protection of the glioma cell 

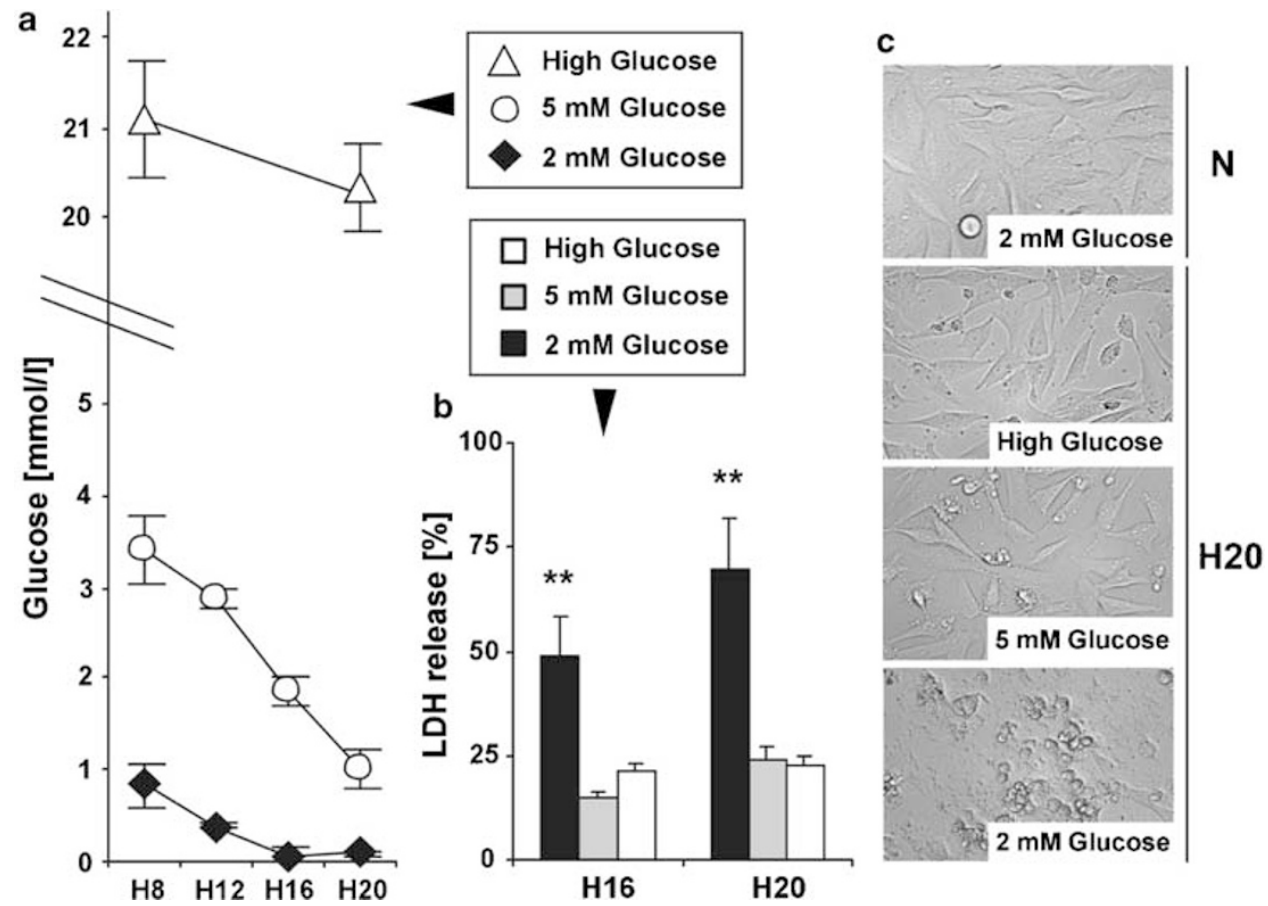

Figure 5 Glucose protects glioma cells from hypoxia-induced cell death. LN-229 cells were exposed to hypoxia in the presence of 2 and $5 \mathrm{mM}$ glucose or serum-free medium ( $25 \mathrm{mM}$ glucose). (a) Glucose concentration was analyzed immediately following hypoxia. (b) In a parallel assay, cell death was assessed by LDH release after $24 \mathrm{~h}$ of normoxic recovery ( ${ }^{* *} P<0.01$ for the comparison of $2 \mathrm{mM}$ Glucose versus $5 \mathrm{mM}$ glucose and $25 \mathrm{mM}$ glucose, student's $t$-test). (c) Phase contrast images of $L \mathrm{~N}$ 229 cells exposed to hypoxia ( $\mathrm{H} 20$ ) or normoxia (N) for $20 \mathrm{~h}$ in the presence of 2 and $5 \mathrm{mM}$ glucose or serum-free medium ( $25 \mathrm{mM}$ glucose) followed by $24 \mathrm{~h}$ of normoxic recovery

lines from hypoxia-induced cell death by higher concentrations of glucose, as described earlier for kidney cells ${ }^{37}$ and astrocytes. ${ }^{38}$ Consistent with this model, cells surviving shorter periods of hypoxia were able to recover and reconstitute normal ATP levels, without the occurrence of delayed cell death. However, once ATP levels were profoundly depleted, progressive cell death ensued even during normoxic incubation with glucose replenishment (Figure 4). Disruption of mitochondria is likely to account for the inability of cells to recover from these conditions. ${ }^{37}$ However, it is notable that delayed cell death following reconstitution of ATP levels after mitochondrial injury in other models is apoptotic. ${ }^{30,37}$

In most paradigms of apoptosis, cytochrome $c$ release results in the formation of a complex, the apoptosome, involving caspase 9 and apoptotic protease activating factor 1 (APAF 1), leading to the cleavage of caspase 9 and subsequently apoptotic cell death. However, ATP is required for the cleavage of caspase 9 by the apoptosome ${ }^{39,40}$ Under conditions of energy failure, caspase 9 activation and subsequent effector caspase activation may be incomplete. ${ }^{41}$ This mechanism in conjunction with the expression of apoptosis-inhibitory proteins of the inhibitor-of-apoptosisprotein (IAP) and BCL-2 family ${ }^{42,43}$ may explain the absence of caspase cleavage and end stages of apoptosis in our paradigm. However, if there is no caspase cleavage, why does ZVAD-fmk protect against hypoxia-induced cell death? Since neither XIAP, which acts on both caspases 3 and 8 , nor $\mathrm{crm}-\mathrm{A}$, which acts predominantly on caspase 8 , or the more specific caspase inhibitors zDEVD-fmk and ZLEHD-fmk alter hypoxia-induced cell death, the protection provided by ZVADfmk may be related to the inhibition of caspases other than 3,7 , 8 or 9 , or to effects of zVAD-fmk on noncaspase proteases. With regard to this possibility, it is well recognized that $\mathrm{ZVAD}$ does not exclusively inhibit caspases (for review of other proteases and references for noncaspase-specific actions of zVAD.fmk see Leist and Jaattela ${ }^{44}$ ). Indeed, inhibition of calpain, the activation of which contributes to necrosis during hypoxic-hypoglycemic-injury (reviewed in Wang ${ }^{45}$ ) by zVAD$\mathrm{fmk}$, has been observed. ${ }^{46}$ We have also considered the possibility of secondary necrosis in our system, which can especially occur following failed apoptosis, for the changes observed following hypoxia and additional normoxic recovery. However, since there was no detectable apoptosis by morphological and biochemical criteria also immediately following hypoxia even at the shortest incubation times resulting in detectable cell death, we dismissed this notion.

Hypoxic cell death in glioma cells resembles death induced by cytotoxic drugs, staurosporine or UV light in APAF 1 knockout embryonic stem cells which undergo nonapoptotic caspase-independent cell death. BCL-2 protects APAF 1 knockout cells by preserving mitochondrial membrane potential independent from caspase activation. ${ }^{47}$ The protection afforded by ectopic BCL- $X_{L}$ expression in our experiments is therefore probably caused by stabilization of mitochondria against hypoxia-induced damage. ${ }^{37,47,48}$ APAF 1- and caspase 3-independent cell death may comprise peripheral chromatin condensation (stage I) similar to our results, in the absence of oligonucleosomal DNA fragmentation. Release of apoptosis inducing factor (AIF) from mitochondria 
a

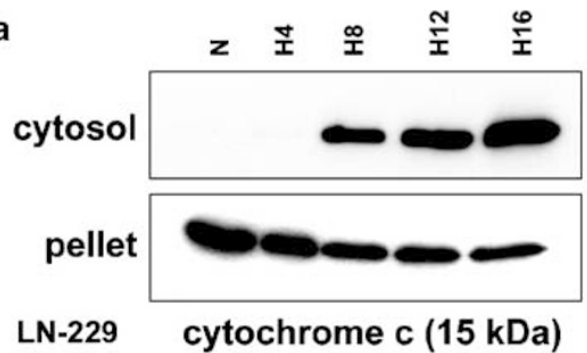

b

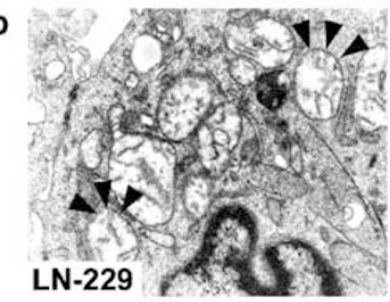

C

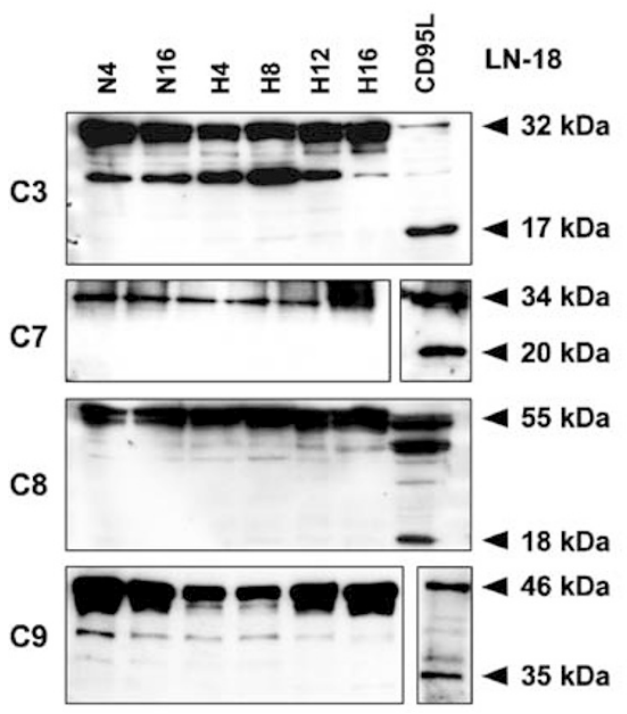

d
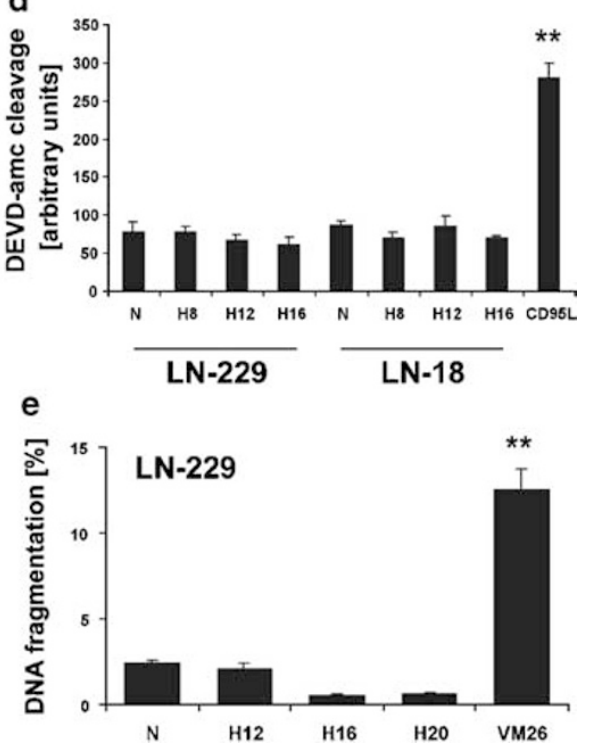

Figure 6 Hypoxia induces mitochondrial injury, but no caspase cleavage or DNA fragmentation. (a) After exposure to normoxia or hypoxia, LN-229 cells were permeabilized with digitonin, and the release of mitochondrial cytochrome $c$ was detected by immunoblot of cytoplasmic proteins. The mitochondrial cytochrome $c$ was analyzed by immunoblot of the pellet fraction. (b) LN-229 cells were exposed to hypoxia for $8 \mathrm{~h}$ and immediately thereafter prepared for electron microscopy. Note the mitochondrial swelling with distension of the cristae (arrowheads). (c) Immunoblots of lysates from LN-18 cells exposed to hypoxia for the times indicated and lysed immediately thereafter was performed with antibodies to caspases 3, 7, 8 or 9. CD95L-treated cells were used as positive control. Note the additional band in blots incubated with antibody to caspase 3 , which may correspond to a band of approximately $24 \mathrm{kDa}$ that is frequently observed in these cells, and is thought to correspond to an inactive intermediate form of caspase 3 processing. (d) LN-229 and LN-18 cells were exposed to normoxia ( $\mathrm{N}$ ) or hypoxia for 8-16 h. DEVD-amc cleavage (expressed in arbitrary units of fluorescence) was determined by fluorimetry $\left({ }^{\star \star} P<0.01\right.$. Student's $t$-test). CD95L-treated cells were used as positive control. (e) $\mathrm{LN}-229 \mathrm{cells}$ were exposed to normoxia or hypoxia for $12-20 \mathrm{~h}$ followed by $24 \mathrm{~h}$ of normoxic recovery. DNA fragmentation was assessed by fluorimetry ( ${ }^{\star \star} P<0.01$, Student's $t$-test) Teniposide (VM26)-treated cells were employed as a positive control (C3, C7, C8, C9: caspases 3, 7, 8, 9)

may act as the critical effector for this phenomenon. ${ }^{49}$ The primary cause of hypoxia-induced mitochondrial injury is unclear. Possibly, ATP depletion itself leads to loss of mitochondrial membrane potential and the observed morphological alterations. Cytochrome $c$ released from mitochondria may then cause an arrest of electron transport within the respiratory chain, resulting in the production of membranedamaging free radicals and cessation of mitochondrial ATP production, further paving the way towards cell death. ${ }^{50}$

In contrast to paradigms where a death stimulus is applied and only the mode of cell death is ATP-dependent, hypoxia per se might not be a sufficient death stimulus in this system. Therefore, we consider energy deprivation as the possible primary cause of cell death in contrast to the models studied by Leist et al. ${ }^{30}$ and others, on which the concept of ATP as a molecular switch between apoptosis and necrosis is based.

Caspase-independent death of cancer cells is increasingly recognized as an important mechanism with implications for the development of novel cancer therapies. Our findings correspond to the predominance of necrosis over apoptosis in human glioblastoma in vivo despite extensive hypoxia, ${ }^{7,16}$, and it appears likely that our model mimics the conditions faced by many tumor cells in the microenvironment of human glioblastoma. Further, the sensitivity of glioma cells to the induction of apoptosis by hypoxia may be important for antiangiogenic therapies, which in other solid tumors so far have had disappointing results in clinical trials. Insight into the mechanisms opposing hypoxia-induced apoptosis may result in strategies to sensitize tumor cells to hypoxia and enhance the impact of antiangiogenic therapy. Finally, this model will be valuable for the study of the effects of other therapies aiming to induce cell death in the hypoxic tumor cell fraction.

\section{Materials and Methods}

\section{Reagents and cell lines}

N-acetyl-Asp-Glu-Val-Asp-7-methyl-4-aminocoumarin (DEVD-amc), Z-Val-AlaAsp-fluoromethylketone (zVAD-fmk) and Z-Leu-Glu-His-Asp-7-methyl- 


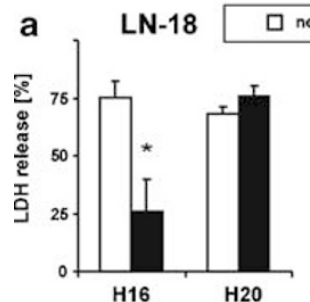
BCL-X $X_{L}$
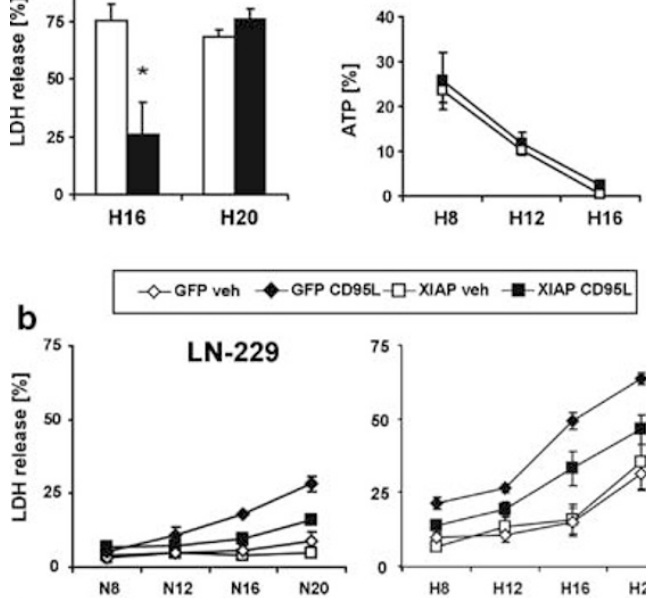

c
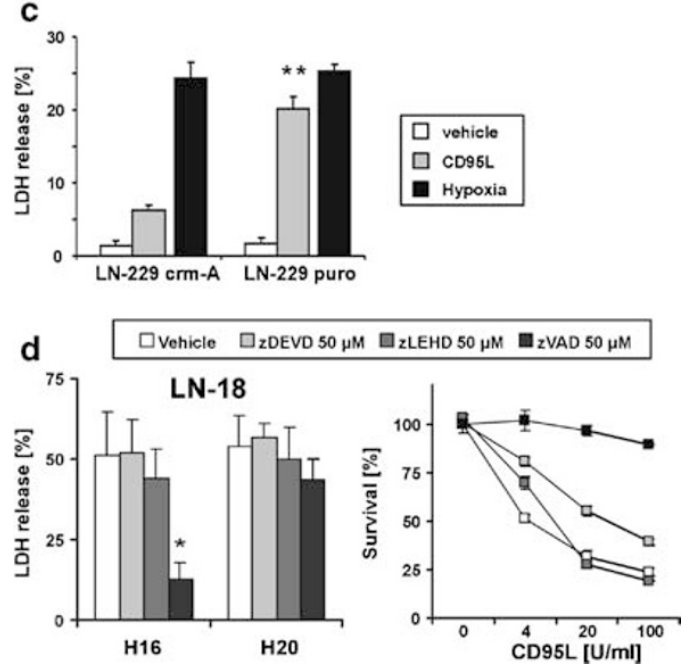

Figure $7 \quad B C L-X_{L}$ confers protection from hypoxia-induced cell death without altering ATP-levels. (a) $\mathrm{LN}-18$ cells engineered to overexpress $B C L-X_{L}$ were exposed to normoxia or hypoxia and analyzed for cytotoxicity by LDH assay after $24 \mathrm{~h}$ of normoxic recovery ${ }^{*} P<0.05$ for the comparison of neo versus BCL-X cells at $16 \mathrm{~h}$, Student's $t$-test) and for ATP immediately following hypoxia ${ }^{\star}{ }^{*} P<0.05$ for the comparison of neo versus $B C L-X_{L}$ cells at $16 \mathrm{~h}$ and $20 \mathrm{~h}$, student's $t$-test). (b) LN-229 cells were transduced with XIAP or GFP by adenoviral gene transfer. At $24 \mathrm{~h}$ after infection, cells were exposed to hypoxia or normoxia in the presence of CD95L $(100 \mathrm{U} / \mathrm{ml})$ or vehicle. Cytotoxicity was assessed by LDH assay. (c) LN-229 crm-A cells or LN-229 puro control cells were incubated under normoxia or hypoxia for $12 \mathrm{~h}$. As a positive control for inhibition of caspase 8-dependent cell death by $\mathrm{crm}-\mathrm{A}$, cells were incubated with $100 \mathrm{U} / \mathrm{ml} \mathrm{CD} 95 \mathrm{~L}$ under normoxia $\left({ }^{\star \star} P<0.001\right.$ for the comparison of $\mathrm{crm}-\mathrm{A}$ versus puro cells following treatment with $\mathrm{CD} 95 \mathrm{~L}$ under normoxia, students $t$ test). (d) $\mathrm{LN}-18$ cells were exposed to normoxia or hypoxia in the presence of $50 \mu \mathrm{M}$ zVAD-fmk, $50 \mu \mathrm{M}$ zDEVD-fmk, $50 \mu \mathrm{M}$ zLEHD-fmk or vehicle. Immediately following hypoxia, cell death was assessed by LDH release assay $\left({ }^{\star} P<0.05\right.$ for the comparison of vehicle versus ZVAD-fmk, student's $t$-test). In a parallel experiment, $L N-18$ cells were exposed to CD95L in the presence of $50 \mu \mathrm{M} \mathrm{zVAD}$ fmk, zDEVD-fmk, zLEHD-fmk or vehicle for $24 \mathrm{~h}$. Survival was assessed by crystal violet staining

4-fluoromethylketone (zLEHD-fmk) were obtained from Bachem (Heidelberg, Germany). Z-Asp-Glu-Val-Asp-7-methyl-4-fluoromethylketone (zDEVD-fmk) was obtained from Calbiochem (Schwalbach, Germany). Teniposide (VM26) was obtained from Bristol (Munich,
Germany). All other chemicals not specified below were purchased from Sigma (Deisenhofen, Germany). CD95 ligand (CD95L) was obtained from the supernatant of CD95L-transfected N2A murine neuroblastoma cells. ${ }^{51}$ LN-18 (p53 mutant), LN-229 and U87MG (both p53 wildtype) human malignant glioma cell lines have been characterized previously. ${ }^{43}$ $\mathrm{LN}-18$ and LN-229 cells transfected with the pSFFV-BCL- $X_{\mathrm{L}}$ construct or an empty neo control vector have been described. ${ }^{36} \mathrm{LN}-229 \mathrm{crm}-\mathrm{A}$ cells were obtained using the Flag-crm-A-puro construct and were compared with puromycin-resistant control cells transfected with the empty vector.

Adenoviral gene transfer of XIAP was performed as described. ${ }^{42}$ Briefly, cells were infected with XIAP-adenovirus or GFP control adenovirus at a multiplicity of infection (MOI) of 300 . At $24 \mathrm{~h}$ after infection, the virus-containing supernatant was removed and cells were incubated under hypoxic or normoxic conditions for the times indicated. Cell death was assessed immediately following hypoxia by LDH-assay.

The glioma cells were maintained in DMEM containing $10 \%$ fetal calf serum, $2 \mathrm{mM}$ glutamine, $100 \mathrm{IU} / \mathrm{ml}$ penicillin and $100 \mathrm{mg} / \mathrm{ml}$ streptomycin.

\section{Induction of hypoxia}

Cells were plated on glass petri dishes of various sizes with cell density adjusted to $5 \times 10^{5} \mathrm{cells} / \mathrm{cm}^{2}$ or on glass 96-well plates (Hellma, Mühlheim, Germany) at a density of $2.5 \times 10^{4} /$ well and allowed to attach in medium containing $10 \%$ fetal calf serum for $24 \mathrm{~h}$. Then the medium was removed and the cells were incubated in serum-free DMEM without glucose (Gibco BRL, Basel, Switzerland) adjusted to $2 \mathrm{mM}$ glucose under normoxia or hypoxia. The experimental conditions have been described previously. ${ }^{52,53}$ Briefly, the cells were incubated in sealed chambers exposed to a mixture of $200 \mathrm{ppm} \mathrm{O}_{2}, 5 \% \mathrm{CO}_{2}$ and $95 \%$ argon or normoxic control conditions in a humified atmosphere. After hypoxia for the times indicated, the cells were allowed to recover for $24 \mathrm{~h}$ with replenishment of glucose to $12.5 \mathrm{mM}$ and addition of $1 \%$ fetal calf serum. For some experiments, the cells were prepared for analysis either immediately after hypoxia or after the $24 \mathrm{~h}$ recovery period. No decrease in $\mathrm{pH}<7.2$ occurred under these conditions. Alternatively, hypoxia was induced chemically by incubating the plates in Gas Pak pouches for anaerobic culture (Becton Dickinson, Heidelberg, Germany). ${ }^{54}$ This procedure results in hypoxia of less than $0.4 \% \mathrm{O}_{2}$ with $4-10 \%$ of $\mathrm{CO}_{2}$ after $100 \mathrm{~min}$. The Gas Pak technique was extensively characterized and yielded identical results compared to gassing with $0.02 \% \mathrm{O}_{2}$ with $5 \% \mathrm{CO}_{2}$ as judged by LDH release assay, caspase cleavage, glucose and ATP depletion and ultrastructural features of cell death.

\section{Electron microscopy}

Glioma cells grown in $60 \mathrm{~mm}$ plates and treated as indicated were fixed in 2.5\% glutaraldehyde (Paesel-Lorei, Frankfurt, Germany) in Hank's modified salt solution (HMSS), postfixed in $1 \% \mathrm{OsO}_{4}$ in $0.1 \mathrm{M}$ cacodylate buffer, scraped off the plastic and dehydrated in ethanol. The $70 \%$ ethanol step was saturated with uranyl acetate for contrast enhancement. Dehydration was completed in propylene oxide. The specimens were embedded in Araldite (Serva, Heidelberg, Germany). Ultrathin sections were produced on an FCR Reichert Ultracut ultramicrotome (Leica, Bensheim, Germany), mounted on pioloform-coated copper grids and contrasted with lead citrate. Specimens were analyzed and documented with an EM 10A electron microscope (Zeiss, Oberkochen, Germany). 


\section{Viability assays}

The cells were seeded in 96-well plates and allowed to attach for $24 \mathrm{~h}$. The cells were exposed to hypoxia or normoxia and treated as indicated. Immediately following hypoxia or after recovery under normoxia, the plates were centrifuged, and the LDH concentration in the supernatant was assessed employing the cell death detection kit II (Boehringer Mannheim, Mannheim, Germany). Crystal violet staining was performed as described. $^{51}$

\section{DEVD-amc-cleaving caspase activity}

The cells were seeded in 96-well plates and allowed to attach for $24 \mathrm{~h}$. The cells were exposed to hypoxia or normoxia and lysed immediately after hypoxia in buffer containing $25 \mathrm{mM}$ Tris- $\mathrm{HCl}(\mathrm{pH} 8.0), 60 \mathrm{mM} \mathrm{NaCl}$, $2.5 \mathrm{mM}$ EDTA and $0.25 \% \mathrm{NP} 40$ for $10 \mathrm{~min}$. DEVD-amc $(12.5 \mu \mathrm{M})$ diluted in PBS was added and incubated at $37^{\circ} \mathrm{C}$ for $10 \mathrm{~min}$. Caspase activity was measured for $1 \mathrm{~h}$ using a CytoFluor 2350 Millipore fluorimeter at $360 \mathrm{~nm}$ excitation and $480 \mathrm{~nm}$ emission wavelengths.

\section{DNA fragmentation assay}

The cells were grown in $60 \mathrm{~mm}$ plates, allowed to attach for $24 \mathrm{~h}$ and exposed to hypoxia or normoxia. After normoxic recovery, the cells were pelleted by centrifugation $\left(7 \mathrm{~min}, 1200 \mathrm{rpm}, 4^{\circ} \mathrm{C}\right)$. The pellet was dissolved in lysis buffer (10 mM Tris-HCl, pH 7.5, $10 \mathrm{mM}$ EDTA, 0.2\% Triton X-100) and lysed for $10 \mathrm{~min}$ at $4^{\circ} \mathrm{C}$. The lysates were centrifuged at $13000 \mathrm{rpm}$ and $4^{\circ} \mathrm{C}$. Supernatant was taken for the measurement of fragmented DNA. The pellet with the intact DNA was again dissolved in lysis buffer and sonified for $20 \mathrm{~s}$. RNase $(100 \mu \mathrm{g} / \mathrm{ml})$ was added to all samples. RNA was digested for $2 \mathrm{~h}$ at $37^{\circ} \mathrm{C}$. All samples were diluted in buffer containing $5 \mathrm{mM}$ TRIS- $\mathrm{HCl}, \mathrm{pH} 7.5,0.5 \mathrm{mM}$ EDTA and $0.5 \mu \mathrm{g} / \mathrm{ml}$ ethidium bromide and measured for the content of DNA using a CytoFluor 2350 Millipore fluorimeter at $530 \mathrm{~nm}$ excitation and $620 \mathrm{~nm}$ emission wavelengths.

\section{Immunoblot analysis}

The cells were grown on $60 \mathrm{~mm}$ plates. Immediately after hypoxia or normoxia, the cells were washed with cold PBS, harvested into ice-cold PBS containing phenylmethyl-sulfonylfluoride (PMSF) $(10 \mu \mathrm{g} / \mathrm{ml})$ with a cell scraper, lysed in lysis buffer containing $50 \mathrm{mM}$ Tris-HCl, pH 8, $120 \mathrm{mM}$ $\mathrm{NaCl}, 0.5 \% \mathrm{NP}-40,100 \mu \mathrm{g} / \mathrm{ml} \mathrm{PMSF}, 10 \mu \mathrm{g} / \mathrm{ml}$ leupeptin and $2 \mu \mathrm{g} / \mathrm{ml}$ aprotinin, for $15 \mathrm{~min}$ on ice and centrifuged at $13000 \mathrm{rpm}$ for $10 \mathrm{~min}$ at $4^{\circ} \mathrm{C}$. The protein concentration was determined by the Bio-Rad Protein Assay (Bio-Rad, Munich, Germany). Soluble proteins ( $20 \mu \mathrm{g} / \mathrm{lane}$ ) were separated by SDS-PAGE and blotted to nitrocellulose by standard procedures. Equal loading was ascertained by Ponceau $S$ staining. The membranes were pretreated for $2 \mathrm{~h}$ with PBS containing $5 \%$ skim milk, $0.05 \%$ Tween 20 and then incubated for $16 \mathrm{~h}$ at $4{ }^{\circ} \mathrm{C}$ with antibodies to caspase 3, BCL- $X_{L}$ (Transduction Laboratories, Lexington, KY, USA), caspases 7, 9 (kindly supplied by Dr. Y Lazebnik, Cold Spring Harbor, NY, USA), caspase 8 (kindly supplied by Dr. PH Krammer, Heidelberg, Germany), BCL-2 (PharMingen, San Diego, CA, USA), BAX and actin (Santa Cruz, San Diego, CA, USA). The secondary antibodies, protein A and anti-mouse $\lg G$, were purchased from Amersham (Braunschweig, Germany), anti-goat antibody was from Santa Cruz. Enhanced chemiluminescence (ECL+, Amersham) was used for detection.

\section{Cytochrome $c$ release assay}

The cells were grown in $100 \mathrm{~mm}$ plates. After hypoxia and immediately following recovery under normoxia, the cells were washed with PBS and cytoplasmatic cytochrome $c$ was extracted by permeabilization with mannitol, sucrose, HEPES (MSH) buffer plus digitonin $(210 \mathrm{mM}$ Dmannitol, $70 \mathrm{mM}$ sucrose, $10 \mathrm{mM}$ HEPES, $200 \mu \mathrm{M}$ EGTA, $5 \mathrm{mM}$ succinate, $0.15 \% \mathrm{BSA}, 40 \mu \mathrm{g} / \mathrm{ml}$ digitonin) at $4^{\circ} \mathrm{C}$. After lysis, the supernatant was removed and centrifuged immediately for $10 \mathrm{~min}$ at $13000 \times \mathrm{g}$. An equal volume of $10 \%$ trichloroacetic acid was added to the supernatant. Samples were kept at $-20^{\circ} \mathrm{C}$ for at least $30 \mathrm{~min}$. After another centrifugation ( $15 \mathrm{~min}$ at $13000 \mathrm{xg}$ ), the pellets were dissolved in sample buffer ( $50 \mathrm{mM}$ TRIS-HCl, pH 6.8, 2\% SDS, 0.1\% bromophenolblue, 10\% glycerol) and analyzed for cytochrome $c$ content by SDS-PAGE and immunoblot, employing mouse monoclonal cytochrome $c$ antibody from PharMingen (San Diego, CA, USA). The mitochondrial cytochrome $c$ content was analyzed by SDS-PAGE from the pellet fraction.

\section{Annexin V binding assay}

The cells were exposed to hypoxia or normoxia as described above. Immediately after hypoxia, or after $24 \mathrm{~h}$ recovery as specified, the cells were washed and stained with propidium iodide and Annexin V (Becton Dickinson PharMingen, Heidelberg, Germany) according to the instructions of the manufacturer. Specific binding was analyzed by FACS utilizing a Becton Dickinson FACSCalibur and the Cell Quest software.

\section{ATP assay}

The cells were exposed to hypoxia or normoxia as described above. Immediately after hypoxia, or after $24 \mathrm{~h}$ recovery as specified, the plates were placed on ice, and the cells were pelleted by centrifugation and lysed in ATP releasing agent (Sigma). ATP was determined by luciferase assay with the CLS II kit (Boehringer Mannheim, Mannheim, Germany). ${ }^{30}$ Typical absolute values for normoxic control cells grown in serum-free medium containing $2 \mathrm{mM}$ glucose were in the region of $2.8 \mathrm{nM} \mathrm{ATP} / \mathrm{mg}$ protein. Values were normalized for $L D H$ release to detect the ATP levels in surviving cells and are given in percentage of values in normoxic control cells. There was no decline in ATP levels $>15 \%$ for up to $20 \mathrm{~h}$ of normoxia with serum-free medium and $2 \mathrm{mM}$ glucose (not shown).

\section{Glucose assay}

The cells were exposed to hypoxia or normoxia as described above. Immediately after hypoxia, the cells were pelleted by centrifugation and the glucose concentration in the supernatant was determined employing the Gluco-quant Glucos/HK Kit (Roche, Basel, Switzerland).

\section{Statistical analysis}

Data are commonly representative of three independent experiments with similar results. Quantitative data are expressed as means and S.D. of triplicate experiments and were assessed for significance by Student's $t$ test.

\section{Acknowledgements}

This study was supported by a grant from the German Cancer Council (101802-We 5) to MW and a grant from the fortüne program of the University of Tübingen to JS (724-0-0). We thank P Supra for excellent technical 
assistance, and H-J Riedinger and G Probst for help with the experimental setup for hypoxic incubation.

\section{References}

1. Rampling $R$, Cruickshank $G$, Lewis $A D$, Fitzsimmons $S A$ and Workman $P$ (1994) Direct measurement of $\mathrm{pO}_{2}$ distribution and bioreductive enzymes in human malignant brain tumors. Int. J. Radiat. Oncol. Biol. Phys. 29: $427-431$

2. Valk PE, Mathis CA, Prados MD, Gilbert JC and Budinger TF (1992) Hypoxia in human gliomas: demonstration by PET with fluorine-18- fluoromisonidazole. J. Nucl. Med. 33: 2133-2137

3. Collingridge DR, Piepmeier JM, Rockwell S and Knisely JP (1999) Polarographic measurements of oxygen tension in human glioma and surrounding peritumoural brain tissue. Radiother. Oncol. 53: 127-131

4. Zagzag D, Amirnovin R, Greco MA, Yee H, Holash J, Wiegand SJ, Zabski S, Yancopoulos GD and Grumet M (2000) Vascular apoptosis and involution in gliomas precede neovascularization: a novel concept for glioma growth and angiogenesis. Lab. Invest. 80: 837-849

5. Holash J, Maisonpierre PC, Compton D, Boland P, Alexander CR, Zagzag D, Yancopoulos GD and Wiegand SJ (1999) Vessel cooption, regression, and growth in tumors mediated by angiopoietins and VEGF. Science 284: 19941998

6. Royds JA, Dower SK, Qwarnstrom EE and Lewis CE (1998) Response of tumour cells to hypoxia: role of p53 and NFkB. Mol. Pathol. 51: 55-61

7. Kleihues P, Burger PC, Collins VP, Newcomb EW, Ohgaki H and Cavenee WK (2000) Glioblastoma. In Pathology and Genetics of Tumours of the Nervous System, Kleihues P and Cavenee WK (eds) (Lyon: IARC Press) pp. 29-39

8. Kimura H, Braun RD, Ong ET, Hsu R, Secomb TW, Papahadjopoulos D, Hong $\mathrm{K}$ and Dewhirst MW (1996) Fluctuations in red cell flux in tumor microvessels can lead to transient hypoxia and reoxygenation in tumor parenchyma. Cancer Res. 56: 5522-5528

9. Helmlinger G, Yuan F, Dellian M and Jain RK (1997) Interstitial pH and $\mathrm{pO}_{2}$ gradients in solid tumors in vivo: high-resolution measurements reveal a lack of correlation. Nat. Med. 3: 177-182

10. Read TA, Sorensen DR, Mahesparan R, Enger PO, Timpl R, Olsen BR, Hjelstuen MH, Haraldseth $O$ and Bjerkvig R (2001) Local endostatin treatment of gliomas administered by microencapsulated producer cells. Nat. Biotechnol. 19: 29-34

11. Machein MR, Risau W and Plate KH (1999) Antiangiogenic gene therapy in a rat glioma model using a dominant-negative vascular endothelial growth factor receptor 2. Hum. Gene Ther. 10: 1117-1128

12. Graeber TG, Osmanian C, Jacks T, Housman DE, Koch CJ, Lowe SW and Giaccia AJ (1996) Hypoxia-mediated selection of cells with diminished apoptotic potential in solid tumours. Nature 379: 88-91

13. Araya $R$, Uehara $T$ and Nomura $Y$ (1998) Hypoxia induces apoptosis in human neuroblastoma SK-N-MC cells by caspase activation accompanying cytochrome $c$ release from mitochondria. FEBS Lett. 439: 168-172

14. Amellem O, Stokke T, Sandvik JA, Smedshammer L and Pettersen EO (1997) Hypoxia-induced apoptosis in human cells with normal p53 status and function, without any alteration in the nuclear protein level. Exp. Cell Res. 232: 361-370

15. Saikumar P, Dong Z, Weinberg JM and Venkatachalam MA (1998) Mechanisms of cell death in hypoxia/reoxygenation injury. Oncogene 17: 3341-3349

16. Tohma Y, Gratas C, Van Meir EG, Desbaillets I, Tenan M, Tachibana O, Kleihues P and Ohgaki H (1998) Necrogenesis and Fas/APO-1 (CD95) expression in primary (de novo) and secondary glioblastomas. J. Neuropathol. Exp. Neurol. 57: 239-245

17. Steinbach JP and Weller M (2002) Mechanisms of apoptosis in CNS tumors: application to theory. Curr. Neurol. Neurosci. Rep. 2: 246-253

18. Tachibana O, Lampe J, Kleihues $P$ and Ohgaki H (1996) Preferential expression of Fas/APO1 (CD95) and apoptotic cell death in perinecrotic cells of glioblastoma multiforme. Acta Neuropathol. 92: 431-434

19. Schiffer D, Cavalla P, Migheli A, Chio A, Giordana MT, Marino S and Attanasio A (1995) Apoptosis and cell proliferation in human neuroepithelial tumors. Neurosci. Lett. 195: 81-84
20. Plate KH, Breier G, Weich HA and Risau W (1992) Vascular endothelial growth factor is a potential tumour angiogenesis factor in human gliomas in vivo. Nature 359: 845-848

21. Dong Z, Venkatachalam MA, Wang J, Patel $Y$, Saikumar $P$, Semenza GL, Force $T$ and Nishiyama J (2001) Up-regulation of apoptosis inhibitory protein IAP-2 by hypoxia. Hif-1-independent mechanisms. J. Biol. Chem. 276: 1870218709

22. Kim CY, Tsai MH, Osmanian C, Graeber TG, Lee JE, Giffard RG, DiPaolo JA, Peehl DM and Giaccia AJ (1997) Selection of human cervical epithelial cells that possess reduced apoptotic potential to low-oxygen conditions. Cancer Res. 57: 4200-4204

23. Teicher BA (1994) Hypoxia and drug resistance. Cancer Metast Rev. 13: 139-168

24. Hockel M, Vorndran B, Schlenger K, Baussmann E and Knapstein PG (1993) Tumor oxygenation: a new predictive parameter in locally advanced cancer of the uterine cervix. Gynecol. Oncol. 51: 141-149

25. Korshunov A, Golanov A, Sycheva R and Pronin I (1999) Prognostic value of tumour associated antigen immunoreactivity and apoptosis in cerebral glioblastomas: an analysis of 168 cases. J. Clin. Pathol. 52: 574-580

26. Rhodes RH (1998) Biological evaluation of biopsies from adult cerebral astrocytomas: cell-growth/cell-suicide ratios and their relationship to patient survival. J. Neuropathol. Exp. Neurol. 57: 746-757

27. Hossmann KA, Mies G, Paschen W, Szabo L, Dolan E and Wechsler W (1986) Regional metabolism of experimental brain tumors. Acta Neuropathol 69: 139-147

28. Mies G, Paschen W, Ebhardt G and Hossmann KA (1990) Relationship between blood flow, glucose metabolism, protein synthesis, glucose and ATP content in experimentally induced glioma (RG1 2.2) of rat brain. J. Neurooncol. 9: $17-28$

29. Vaupel $P$ (1992) Physiological properties of malignant tumours. NMR Biomed 5: 220-225

30. Leist M, Single B, Castoldi AF, Kuhnle S and Nicotera P (1997) Intracellular adenosine triphosphate (ATP) concentration: a switch in the decision between apoptosis and necrosis. J. Exp. Med. 185: 1481-1486

31. Eguchi Y, Shimizu S and Tsujimoto Y (1997) Intracellular ATP levels determine cell death fate by apoptosis or necrosis. Cancer Res. 57: 1835-1840

32. Weller M, Frei K, Groscurth $\mathrm{P}$, Krammer PH, Yonekawa $\mathrm{Y}$ and Fontana $\mathrm{A}$ (1994) Anti-Fas/APO-1 antibody-mediated apoptosis of cultured human glioma cells. Induction and modulation of sensitivity by cytokines. J Clin Invest 94: 954-964

33. Glaser T, Wagenknecht B, Groscurth P, Krammer PH and Weller M (1999) Death ligand/receptor-independent caspase activation mediates drug-induced cytotoxic cell death in human malignant glioma cells. Oncogene 18: 5044-5053

34. Hermisson M, Wagenknecht B, Wolburg H, Glaser T, Dichgans $\mathrm{J}$ and Weller $\mathrm{M}$ (2000) Sensitization to CD95 ligand-induced apoptosis in human glioma cells by hyperthermia involves enhanced cytochrome $c$ release. Oncogene 19: 2338-2345

35. Gerweck LE, Seneviratne T and Gerweck KK (1993) Energy status and radiobiological hypoxia at specified oxygen concentrations. Radiat Res 135: 69-74

36. Glaser T, Wagenknecht B and Weller M (2001) Identification of p21 as a target of cycloheximide-mediated facilitation of CD95-mediated apoptosis in human malignant glioma cells. Oncogene 20: 4757-4767

37. Saikumar P, Dong Z, Patel Y, Hall K, Hopfer U, Weinberg JM and Venkatachalam MA (1998) Role of hypoxia-induced Bax translocation and cytochrome $c$ release in reoxygenation injury. Oncogene 17: 3401-3415

38. Callahan DJ, Engle MJ and Volpe JJ (1990) Hypoxic injury to developing glial cells: protective effect of high glucose. Pediatr. Res. 27: 186-190

39. Li P, Nijhawan D, Budihardjo I, Srinivasula SM, Ahmad M, Alnemri ES and Wang X (1997) cytochrome $c$ and dATP-dependent formation of Apaf-1/ caspase-9 complex initiates an apoptotic protease cascade. Cell 91: 479-489

40. Slee EA, Harte MT, Kluck RM, Wolf BB, Casiano CA, Newmeyer DD, Wang HG, Reed JC, Nicholson DW, Alnemri ES, Green DR and Martin SJ (1999) Ordering the cytochrome $c$-initiated caspase cascade: hierarchical activation of caspases-2, -3, -6, -7, -8, and -10 in a caspase-9- dependent manner. J. Cell Biol. 144: 281-292

41. Eguchi Y, Srinivasan A, Tomaselli KJ, Shimizu S and Tsujimoto Y (1999) ATP-dependent steps in apoptotic signal transduction. Cancer Res. 59: 2174-2181 
42. Wagenknecht B, Glaser T, Naumann U, Kugler S, Isenmann S, Bahr M, Korneluk R, Liston P and Weller M (1999) Expression and biological activity of X-linked inhibitor of apoptosis (XIAP) in human malignant glioma. Cell Death Differ 6: 370-376

43. Weller M, Rieger J, Grimmel C, Van Meir EG, De Tribolet N, Krajewski S, Reed $\mathrm{JC}$, von Deimling A and Dichgans J (1998) Predicting chemoresistance in human malignant glioma cells: the role of molecular genetic analyses. Int. J. Cancer 79: 640-644

44. Leist $M$ and Jaattela $M$ (2001) Four deaths and a funeral: from caspases to alternative mechanisms. Nat Rev Mol Cell Biol 2: 589-598

45. Wang KK (2000) Calpain and caspase: can you tell the difference? Trends Neurosci 23: 20-26

46. Waterhouse NJ, Finucane DM, Green DR, Elce JS, Kumar S, Alnemri ES, Litwack G, Khanna K, Lavin MF and Watters DJ (1998) Calpain activation is upstream of caspases in radiation-induced apoptosis. Cell Death Differ 5: 1051-1061

47. Haraguchi M, Torii S, Matsuzawa S, Xie Z, Kitada S, Krajewski S, Yoshida H, Mak TW and Reed JC (2000) Apoptotic protease activating factor 1 (Apaf-1)independent cell death suppression by Bcl-2. J Exp Med 191: 1709-1720

48. Green DR and Reed JC (1998) Mitochondria and apoptosis. Science 281: $1309-1312$
49. Susin SA, Daugas E, Ravagnan L, Samejima K, Zamzami N, Loeffler M, Costantini P, Ferri KF, Irinopoulou T, Prevost MC, Brothers G, Mak TW, Penninger J, Earnshaw WC and Kroemer G (2000) Two distinct pathways leading to nuclear apoptosis. J Exp Med 192: 571-580

50. Reed JC (1997) cytochrome $c$ : can't live with it-can't live without it. Cell 91: 559-562

51. Roth W, Fontana A, Trepel M, Reed JC, Dichgans J and Weller M (1997) Immunochemotherapy of malignant glioma: synergistic activity of CD95 ligand and chemotherapeutics. Cancer Immunol. Immunother. 44: 55-63

52. Probst $H$, Schiffer $H$, Gekeler V, Kienzle Pfeilsticker $H$, Stropp U, Stotzer KE and Frenzel-Stotzer I (1988) Oxygen dependent regulation of DNA synthesis and growth of Ehrlich ascites tumor cells in vitro and in vivo. Cancer Res. 48: 2053-2060

53. Dreier T, Scheidtmann KH and Probst $H$ (1993) Synchronous replication of SV 40 DNA in virus infected TC 7 cells induced by transient hypoxia. FEBS Lett. 336: $445-451$

54. Kendler A and Dawson G (1990) Progressive hypoxia inhibits the de novo synthesis of galactosylceramide in cultured oligodendrocytes. J Biol Chem 265: 12259-12266 